\title{
Fast assembly of non-thiolated DNA on gold surface at lower
}

\section{pH}

Hui Jiang ${ }^{1}$, Elsa M. Materon ${ }^{2,3}$, Maria Del Pilar Taboada Sotomayor ${ }^{3}$, and Juewen Liu² ${ }^{2}$

1 State Key Laboratory of Bioelectronics, Southeast University, 2 Sipailou, Nanjing, P. R. China 210096;

2 Department of Chemistry and Waterloo Institute for Nanotechnology, University of Waterloo, 200 University Avenue West, Waterloo, Ontario, Canada N2L 3G1

3 Department of Analytical Chemistry, Institute of Chemistry, State University of São Paulo (UNESP), 14801-970 Araraquara, SP, Brazil

* Corresponding author.

Fax: +1 5197460435

Email: liujw@uwaterloo.ca

The final publication is available at Elsevier via http://dx.doi.org/10.1016/j.jcis.2013.08.043 @ 2013. This manuscript version is made available under the CC-BY-NC-ND 4.0 license http:// creativecommons.org/licenses/by-nc-nd/4.0/ 


\begin{abstract}
In a typical protocol for attaching DNA to a gold electrode, thiolated DNA is incubated with the electrode at neutral $\mathrm{pH}$ overnight. Here we report fast adsorption of non-thiolated DNA oligomers on gold electrodes at acidic $\mathrm{pH}$ (i.e., $\mathrm{pH} \sim 3.0$ ). The peak-to-peak potential difference and the redox peak currents in typical cyclic voltammetry of $\left[\mathrm{Fe}(\mathrm{CN})_{6}\right]^{3-}$ are investigated to monitor the attachment. Compared with incubation at neutral $\mathrm{pH}$, the lower $\mathrm{pH}$ can significantly promote the adsorption processes, enabling efficient adsorption even in $30 \mathrm{~min}$. The adsorption rate is DNA concentration-dependent, while the ionic strength shows no influence. Moreover, the adsorption is base-discriminative, with a preferred order of $A>C>>G$, T, which is attributed to the protonation of $\mathrm{A}$ and $\mathrm{C}$ at low $\mathrm{pH}$ and their higher binding affinity to gold surface. The immobilized DNA is functional and can hybridize with its complementary DNA but not a random DNA. This work is promising to provide a useful time-saving strategy for DNA assembly on gold electrodes, allowing fast fabrication of DNA-based biosensors and devices.
\end{abstract}




\section{Introduction}

Analytical methods based on surface immobilized DNA probes for target recognition have been extensively explored in the past decades [1-8]. Not only complementary nucleic acids but also many other analytes have been detected when DNA aptamers and DNAzymes are used [9-16]. Typically, the probe DNA is labeled with a thiol group and immobilized on a gold surface or electrode, where the incubation buffer often contains high salt (e.g. $1 \mathrm{M} \mathrm{KH}_{2} \mathrm{PO}_{4}$ ) at neutral pH [17]. While effective, the traditional process is time-consuming [17-19]. For example, thiolated DNA is typically assembled on $\mathrm{Au}$ surface after overnight incubation. This is partially due to the electrostatic repulsion between gold surface and DNA [18]. At the same time, DNA bases can also adsorb onto the gold surface, and their displacement by the thiol label can also be time consuming $[18,20]$. In addition, it has also been established that the DNA density cannot be too high; otherwise hybridization with target is hindered by steric and electrostatic effects [21]. The precise control over the DNA density on gold surface remains quite challenging since DNA density is quite insensitive to the initial DNA concentration used for incubation [18]. Often it has to be controlled by tuning the incubation time. In addition, DNA needs to be in an upright conformation for hybridization, which is often achieved via back-filling with short alkanethiol compounds [17].

It has been realized that even non-thiolated DNA can tightly adsorb onto gold surface via a poly-adenine tail [22-25]. The DNA density and conformation can be tuned by changing the length of the poly-adenine block, where a longer poly-adenine block should produce more sparsely distributed DNA. The attachment of non-thiolated DNA has also recently been demonstrated on gold nanoparticles (AuNPs) using a similar poly-adenine anchoring strategy [26-28]. In addition to these advantages, the cost of thiolated DNA is about ten to twenty-fold higher compared to the non-thiolated counterpart. To further advance these sensors for practical applications, it is highly desirable to reduce the cost of DNA synthesis and to achieve high speed DNA attachment.

Recently, our group has studied the adsorption of DNA by citrate-capped AuNPs, where quick DNA loading was achieved in a few minutes at low $\mathrm{pH}[28,29]$. The reason for the low $\mathrm{pH}$ strategy 
to work is because of protonation of the adenine and cytosine bases, reducing the electrostatic repulsion with the negatively AuNP surface, which is capped by citrate. Herein we aim to test whether the low $\mathrm{pH}$ method could be applied to non-thiolated DNA immobilization on gold electrodes and explore the effect of DNA sequence, concentration, ionic strength and $\mathrm{pH}$. This work may offer a time-saving and low-cost strategy for preparation of DNA biosensors.

\section{Experimental}

\subsection{Reagents}

DNA oligomers were obtained from Integrated DNA Technologies (Coralville, IA, USA). The DNA sequences (and abbreviations) are listed as following:

SH-DNA1: 5'-SH-AAAAAAAAACCCAGGTTCTCT;

DNA1: AAAAAAAAACCCAGGTTCTCT;

cDNA: 5'-ACGCATCTGTGAAGAGAACCTGGG

Hairpin: 5'-(A), GCATATCGCCCCCCCCCCCCGATATGC;

Poly-N $15, \mathrm{~N}=\mathrm{A}, \mathrm{T}, \mathrm{C}, \mathrm{G}$; and $\mathrm{A}_{5}$.

DNA stock solutions of $200 \mu \mathrm{M}$ were prepared and stored at $-20 \quad{ }^{\circ} \mathrm{C}$. Adenosine-5'-monophosphate (AMP), adenosine-5'- triphosphate (ATP), $\mathrm{K}_{3}\left[\mathrm{Fe}(\mathrm{CN})_{6}\right]$, and hexaammineruthenium (III) chloride were purchased from Sigma-Aldrich (St. Loius, MO, USA). All other reagents are of analytical grade. The $\mathrm{pH}$ of citrate buffer (CB) was adjusted by changing the ratio of sodium citrate and citric acid. Phosphate buffer was prepared using $\mathrm{NaH}_{2} \mathrm{PO}_{4}$ and $\mathrm{Na}_{2} \mathrm{HPO}_{4}$. Deionized water was used throughout.

\subsection{Apparatus}

The cyclic voltammetric (CV) studies were performed on a CHI604 electrochemical workstation (Austin, TX, USA) at $20 \pm 2{ }^{\circ} \mathrm{C}$ in a three-electrode electrochemical cell consisting of a bare or treated gold electrode ( $3 \mathrm{~mm}$ in diameter) as the working electrode, a Pt wire as the counter electrode and a saturated calomel electrode (SCE) or $\mathrm{Ag} / \mathrm{AgCl}$ electrode as the 
reference electrode. Before each use, a gold electrode was cleaned with piranha solution for 25 min to remove organic impurities and then rinsed with water (Milli-Q). The gold surface was polished with a polishing kit (CH Instruments, Austin, TX, USA), using $1.0 \mu \mathrm{m}$ alpha alumina powder, $0.3 \mu \mathrm{m}$ alpha alumina powder, and $0.05 \mu \mathrm{m}$ gamma alumina powder. The gold surface was rinsed with water between each polishing step and ultrasonically cleaned with ethanol and distilled water for $30 \mathrm{~min}$. Finally the electrodes were rinsed with water and dried with a stream of nitrogen gas. In order to reduce the surface roughness and improve the reproducibility the gold electrode was electrochemistry cycled $(30$ cycles and $100 \mathrm{mV} / \mathrm{s})$ from potential of -0.2 to 1.6 $\mathrm{V}$ vs $\mathrm{Ag} / \mathrm{AgCl}$ in $1 \mathrm{M} \mathrm{H}_{2} \mathrm{SO}_{4}$ solution until stable $\mathrm{CV}$ curves are obtained. The Raman spectra are performed on a BWS435-532SY confocal microscopic Raman spectrometer (BWTek, DE, USA).

\subsection{Adsorption of DNA oligomers on gold electrodes}

$2 \mu \mathrm{L}$ DNA oligomers in buffer solution is cast on the clean gold electrode and then capped with an EP tube to minimize evaporation. After incubation for a certain time, the electrodes are carefully rinsed with deionized water to remove the excess DNA, dried with nitrogen and perform $\mathrm{CV}$ measurement in the detection solution containing $1 \mathrm{mM} \mathrm{K} 3\left[\mathrm{Fe}(\mathrm{CN})_{6}\right]$ and $0.1 \mathrm{M} \mathrm{KNO}_{3}$ (scan rate $\left.0.1 \mathrm{~V} \mathrm{~s}^{-1}\right)$. The similarly treated electrodes are prepared for Raman research.

\subsection{Methods for DNA hybridization}

The clean gold electrode was submersed in $5 \mu \mathrm{M}$ non-thiolated DNA1 (or DNA1) in $250 \mathrm{mM}$ citrate buffer (pH 3) for 30 min. For $\mathrm{pH} 7$ incubation, the buffer was $25 \mathrm{mM}$ phosphate with $25 \mathrm{mM}$ $\mathrm{NaCl}$. The modified electrode was rinsed with $25 \mathrm{mM}$ PBS buffer ( $\mathrm{pH} 7$ ) to remove probes that were non-specifically absorbed. Electrochemistry measurements were performed in electrolyte solution containing $\mathrm{K}_{3}\left[\mathrm{Fe}(\mathrm{CN})_{6}\right]$ in $0.1 \mathrm{M}$ PBS pH 7.0 (scan rate $0.1 \mathrm{~V} \mathrm{~s}^{-1}$ ).

To measure DNA hybridization, gold electrodes modified with probe DNA were exposed to 500 $\mathrm{nM}$ mercaptohexanol $(\mathrm{MCH})$ for $1 \mathrm{~h}$, followed by rinsing with $25 \mathrm{mM}$ PBS (pH 7) and incubation at $60{ }^{\circ} \mathrm{C}$ for $10 \mathrm{~min}$ in hybridization solution $(25 \mathrm{mM}$ sodium phosphate, $\mathrm{pH} 7.0,25 \mathrm{mM} \mathrm{NaCl}, 2$ 
$\mathrm{mM} \mathrm{MgCl}_{2}$ and $2 \mu \mathrm{M}$ target DNA) and then at room temperature for $1 \mathrm{~h}$. The electrolyte solution for detection of hybridization contained $25 \mathrm{mM}$ of phosphate ( $\mathrm{pH} 7.0$ ), $25 \mathrm{mM} \mathrm{NaCl}$, and $27 \mu \mathrm{M}$ $\mathrm{Ru}\left(\mathrm{NH}_{3}\right)_{6}{ }^{3+}$. The hybridized DNA can bind to the ruthenium complex that generates electrochemical signal $[30,31]$.

\section{Results and Discussion}

Adsorption of DNA oligomers on gold electrode is a complicated kinetic process [32]. Until now one of the most common strategies for DNA immobilization on gold electrode is the formation of thiolated DNA self-assembly monolayer (SAM) via the strong Au-S bond. This robust method is, however, expensive and time consuming. In this work we have devoted to the fast immobilization of non-thiolated DNA on gold electrode. Before testing non-thiolated DNA, we carried out an initial test on a thiolated DNA (SH-DNA1), where it was incubated with the electrode at pH 3 or pH 7. After washing away free DNA, DNA immobilization was checked by the redox signal of $\left[\mathrm{Fe}(\mathrm{CN})_{6}\right]^{3-}$. As shown in Fig. 1A, the clean electrode has a strong signal, suggesting good accessibility of the electrode surface. After incubation in the $\mathrm{pH} 7$ buffer without additional salt, the electrode response did not change significantly, suggesting a very low density of DNA was immobilized. This low immobilization efficiency is attributed to the low salt concentration and short incubation time used in the incubation step. For example, effective DNA adsorption on a gold electrode surface typically requires $1 \mathrm{M}$ salt [17]. A large drop in the current was observed with incubation in the pH 3 buffer (Fig. 1B), where the electrode surface was almost completely blocked by the adsorbed DNA layer. This experiment confirmed that the low $\mathrm{pH}$ method works also for the bulk gold surface in addition to AuNPs. Similar observation was achieved with non-thiolated DNA of the same sequence, which will be the focus of this study. 

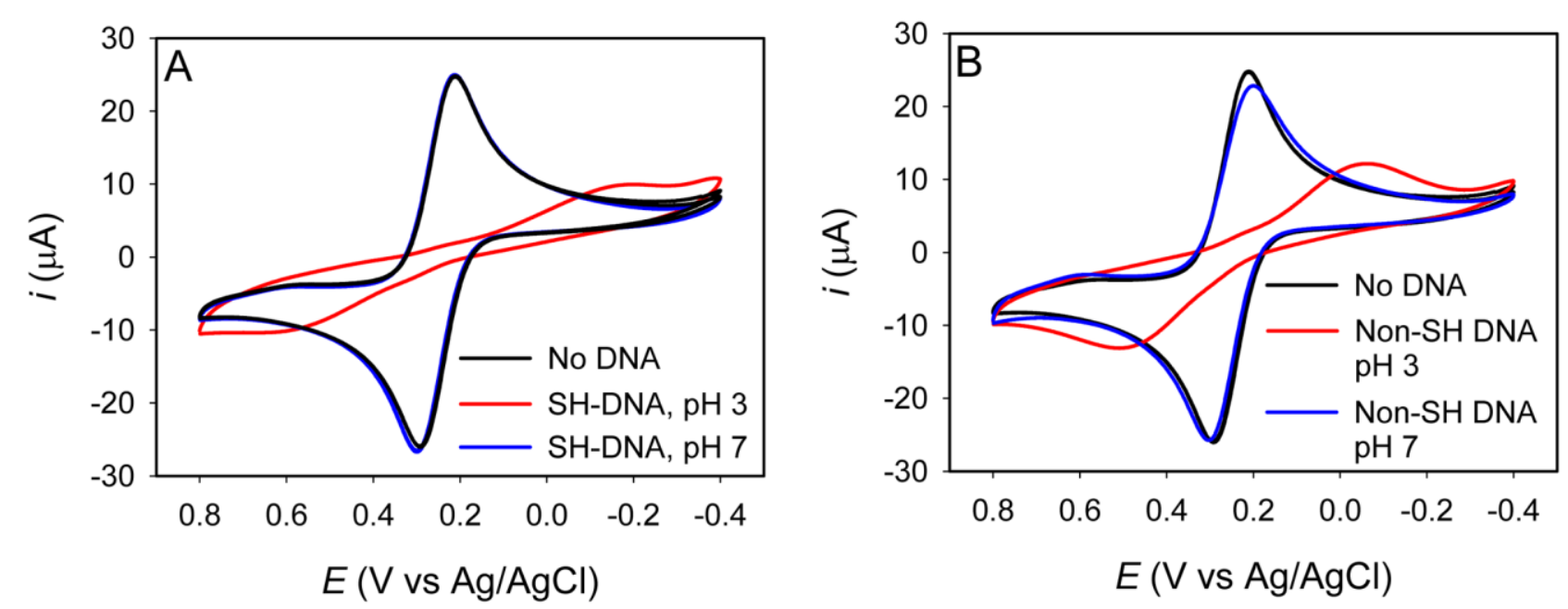

Fig. 1. $\mathrm{CV}$ curves of $2 \mathrm{mM}\left[\mathrm{Fe}(\mathrm{CN})_{6}\right]^{3-}$ on gold electrodes before and after treating thiolated DNA (A) and non-thiolated DNA (B) at $\mathrm{pH} 3$ or $\mathrm{pH}$ 7. A low current indicates DNA immobilization and blockage of the electrode surface. Only the DNA immobilization step was carried out in different $\mathrm{pH}$; the measurement was in $\mathrm{pH} 7$ PBS buffer.

To systematically study immobilization of non-thiolated DNA, we employed a hairpin DNA with an 9-adenine overhang on the 5'-end, since it is known that adenine base has strong affinity to gold surface. Note that no thiol label was used in this DNA. To probe the adsorption reaction, the redox signal of $\left[\mathrm{Fe}(\mathrm{CN})_{6}\right]^{3-}$ was monitored. We first studied the effect of $\mathrm{pH}$. Clean bare gold electrodes are treated with $5 \mu \mathrm{M}$ hairpin DNA in $\mathrm{CB}$ with $\mathrm{pH}$ range from 3.0 to 7.0 (Fig. 2B). After 15 min incubation, the redox behavior of $\left[\mathrm{Fe}(\mathrm{CN})_{6}\right]^{3-}$ on gold electrode for $\mathrm{pH}$ at or above 5.0 (curve $\mathrm{c}, \mathrm{d}$ ) is almost as reversible as that obtained on the gold electrode without any DNA treatment (curve e), indicating negligible DNA adsorption on gold electrode. DNA appears to show moderate adsorption at $\mathrm{pH} 4.0$ (curve b) and adsorption becomes much more significant at $\mathrm{pH} 3.0$ (curve a) since the $\left[\mathrm{Fe}(\mathrm{CN})_{6}\right]^{3-}$ signal was greatly reduced under these conditions. To make quantitative comparison, we monitored two parameters. One is the shift in peak-to-peak potential difference $\left[\Delta\left(\Delta \mathrm{E}_{\mathrm{p}}\right)=\left(\Delta \mathrm{E}_{\mathrm{p}}-\Delta \mathrm{E}_{\mathrm{p} 0}\right)\right]$, where $\Delta \mathrm{E}_{\mathrm{p}}$ and $\Delta \mathrm{E}_{\mathrm{p} 0}$ represent the peak-to-peak potential difference on the treated and control electrode, respectively. $\Delta\left(\Delta \mathrm{E}_{\mathrm{p}}\right)$ is an indication of DNA 
adsorption. The other is the remaining percentage of redox peak currents $\left(I_{p} / I_{p 0}\right)$, where $I_{p}$ and $I_{p 0}$ represent the mean value of the peak currents of redox pairs on the treated and control electrode, respectively. $\Delta\left(\Delta \mathrm{E}_{\mathrm{p}}\right)$ shifts up to $150 \mathrm{mV}$ at $\mathrm{pH} 3.0$ and $80 \mathrm{mV}$ at $\mathrm{pH} 4.0$ (Fig. 2C), while the current decreases to $\sim 60 \%$ at $\mathrm{pH} 4.0$ and only $\sim 20 \%$ at $\mathrm{pH} 3.0$ (Fig. 2D). Both sharp increase in $\left[\Delta\left(\Delta \mathrm{E}_{\mathrm{p}}\right)\right]$ and simultaneous decrease in $\mathrm{I}_{\mathrm{p}} / \mathrm{I}_{\mathrm{p} 0}$ are incubation time-dependent and reach a plateau in less than 15 min at $\mathrm{pH} 3$ and in $\sim 30$ min at $\mathrm{pH} 4$, indicating the saturation of DNA adsorbed. Compared with the equilibrium established in only $\sim 3$ min between DNA and Au NPs in homogeneous solution $[[28,33]]$, the current adsorption is slightly slower, which is attributed to the heterogeneous phase processes.

To exclude the possible adsorption of citrate on gold electrode, $0.1 \mathrm{M}$ phosphate buffer at $\mathrm{pH}$ 3.0 was also applied in the same experiment. Similar results were observed, where saturated DNA adsorption was achieved in $\sim 30 \mathrm{~min}$ (data not shown). Therefore the lost of $\left[\mathrm{Fe}(\mathrm{CN})_{6}\right]^{3-}$ signal could only be due to DNA adsorption. We reason that partial protonation of adenine $\left(\mathrm{pK}_{\mathrm{a}}=3.5\right)$ and cytosine $\left(\mathrm{pK}_{\mathrm{a}}=4.2\right)$ at low $\mathrm{pH}$ has reduced the density of negative charges on DNA, affording faster DNA adsorption. 
(A)

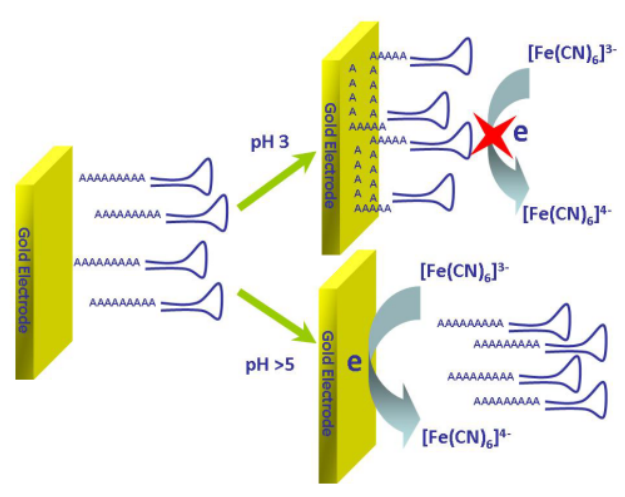

(C)

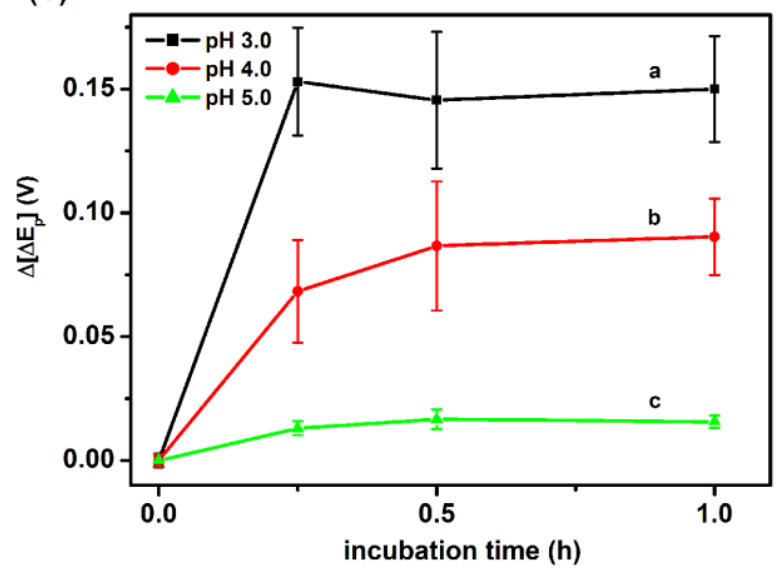

(B)

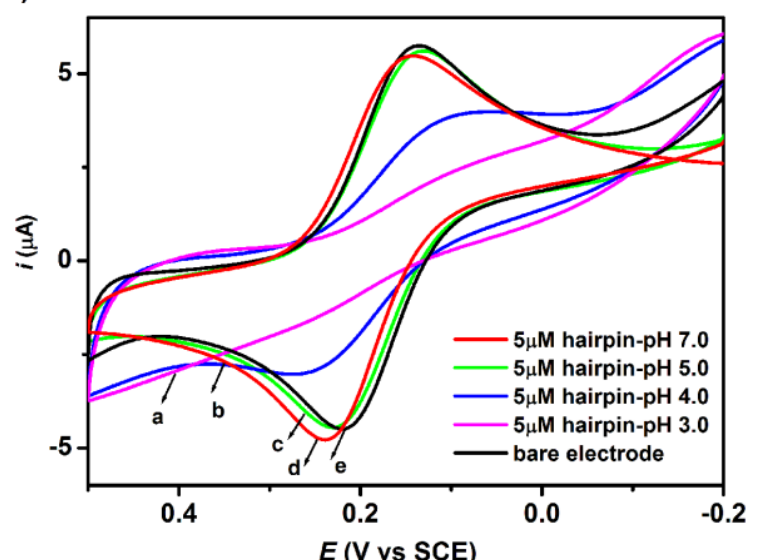

(D)

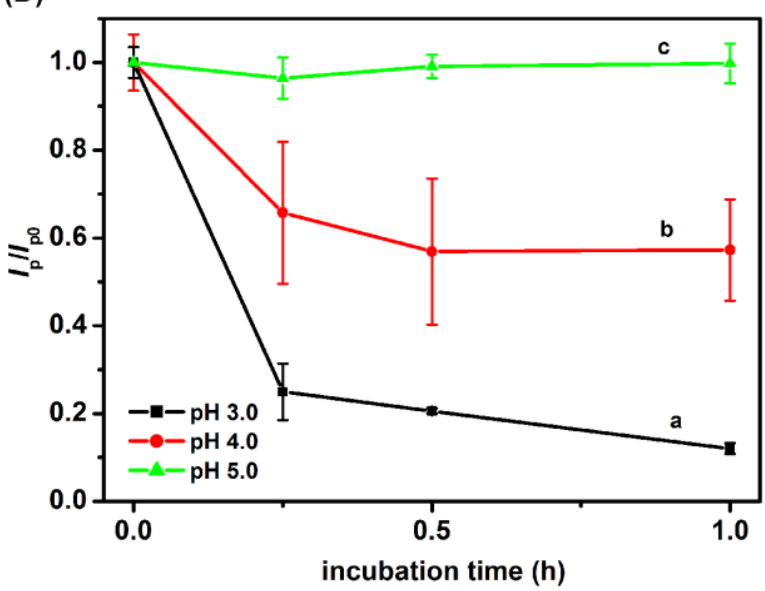

Fig. 2. (A) Schematic illustration of poly-A tagged hairpin DNA adsorption on a gold electrode at different $\mathrm{pH}$. (B) $\mathrm{CV}$ curves of $\left[\mathrm{Fe}(\mathrm{CN})_{6}\right]^{3-}$ on gold electrodes after treating the electrodes with 5 $\mu \mathrm{M}$ hairpin DNA in $250 \mathrm{mM} \mathrm{CB}$ of $\mathrm{pH} 3.0$ (a), 4.0 (b), 5.0 (c) or 7.0 (d) for 15 min or only treated with $\mathrm{CB}$ of $\mathrm{pH} 3.0$ (e). (C) and (D) respectively show the dependence of $\left[\Delta\left(\Delta \mathrm{E}_{\mathrm{p}}\right)\right]$ and $\mathrm{I}_{\mathrm{p}} / \mathrm{I}_{\mathrm{p} 0}$ on incubation time when the electrodes are treated with $5 \mu \mathrm{M}$ hairpin DNA at pH 3.0 (a), 4.0 (b) or 5.0 (c). 
(A)

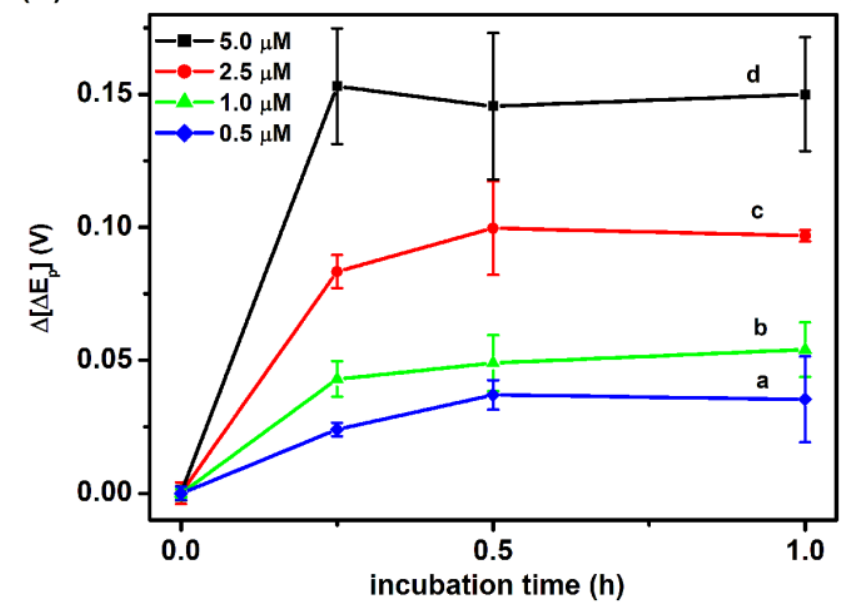

(B)

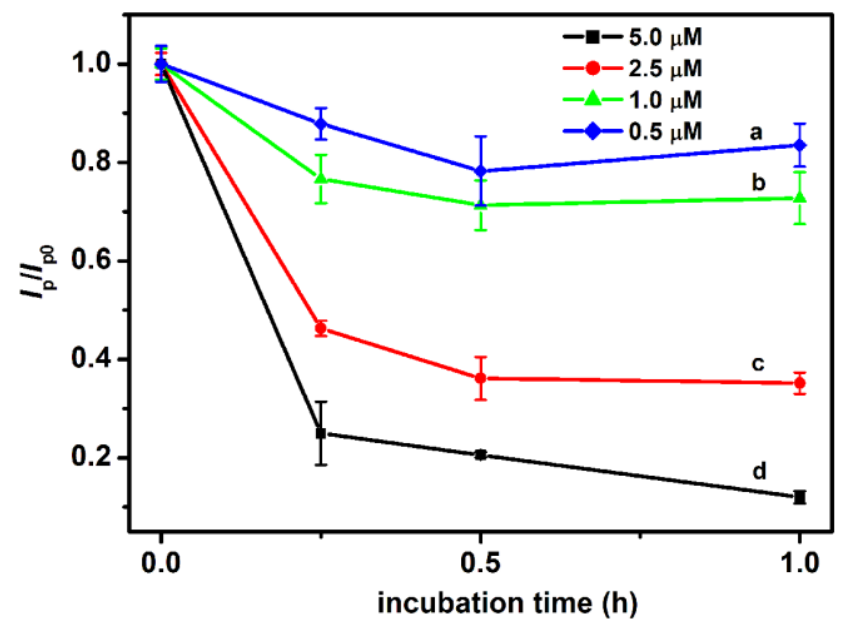

(C)

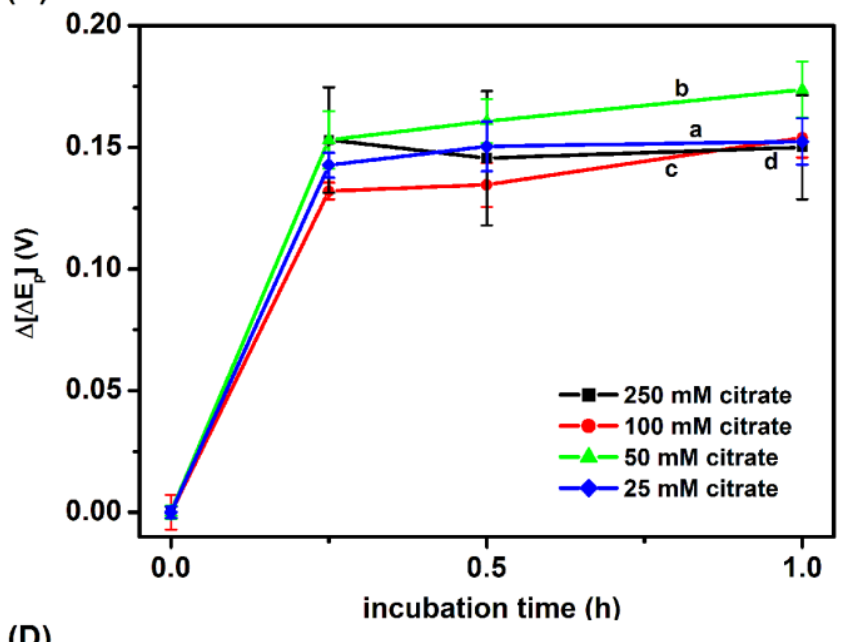

(D)

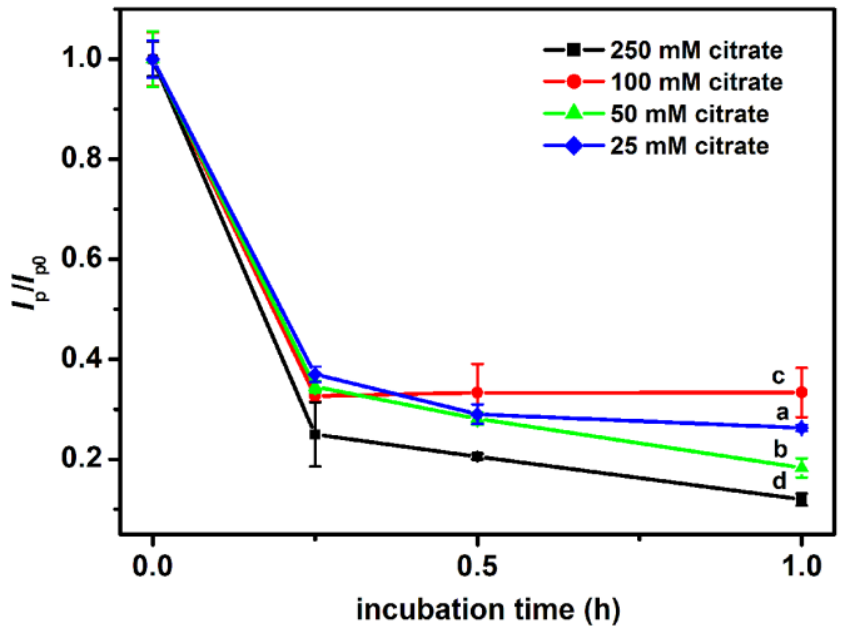

Fig. 3. The dependence of $\left[\Delta\left(\Delta \mathrm{E}_{\mathrm{p}}\right)\right](\mathrm{A})$ and $\mathrm{I}_{\mathrm{p}} / \mathrm{I}_{\mathrm{p} 0}(\mathrm{~B})$ on incubation time when the electrodes are treated with 0.5 (a), 1.0 (b), 2.5 (c), or 5.0 (d) $\mu \mathrm{M}$ hairpin DNA at $\mathrm{pH}$ 3.0, respectively. And the dependence of $\left[\Delta\left(\Delta \mathrm{E}_{\mathrm{p}}\right)\right](\mathrm{C})$ and $\mathrm{I}_{\mathrm{p}} / \mathrm{I}_{\mathrm{p} 0}(\mathrm{D})$ on incubation time when the electrodes are treated with $5.0 \mu \mathrm{M}$ hairpin DNA in 25 (a), 50 (b), 100 (c), or 250 (d) mM CB (pH 3.0), respectively.

Subsequently, the DNA concentration effect on the adsorption processes was investigated. It is reasonable that the higher DNA concentration may result in higher DNA coverage on gold electrode in short time, thus excluding the negative-charged $\left[\mathrm{Fe}(\mathrm{CN})_{6}\right]^{3-}$ in the vicinity of electrode and impeding the effective electron exchange between $\left[\mathrm{Fe}(\mathrm{CN})_{6}\right]^{3-}$ and electrode. For all cases, the adsorption process tends to saturate after $30 \mathrm{~min}$ (Fig. $3 \mathrm{~A}, \mathrm{~B}$ ), indicating the solid-liquid interfacial equilibrium between gold electrode and DNA. 
The possible ionic strength effect on the low-pH induced fast adsorption is also investigated (Fig. 3 C, D). The ionic strength is typically a key factor in directing electrostatic related binding process. Interestingly, no significant difference was observed for $\left[\Delta\left(\Delta \mathrm{E}_{\mathrm{p}}\right)\right]$ or $\mathrm{I}_{\mathrm{p}} / \mathrm{I}_{\mathrm{p} 0}$ in the $\mathrm{CB}$ concentrations from 25 to $250 \mathrm{mM}$ at $\mathrm{pH}$ 3. This suggests that at low $\mathrm{pH}$, the buffer or salt concentration plays very minor role on the DNA adsorption behaviors.

(A)

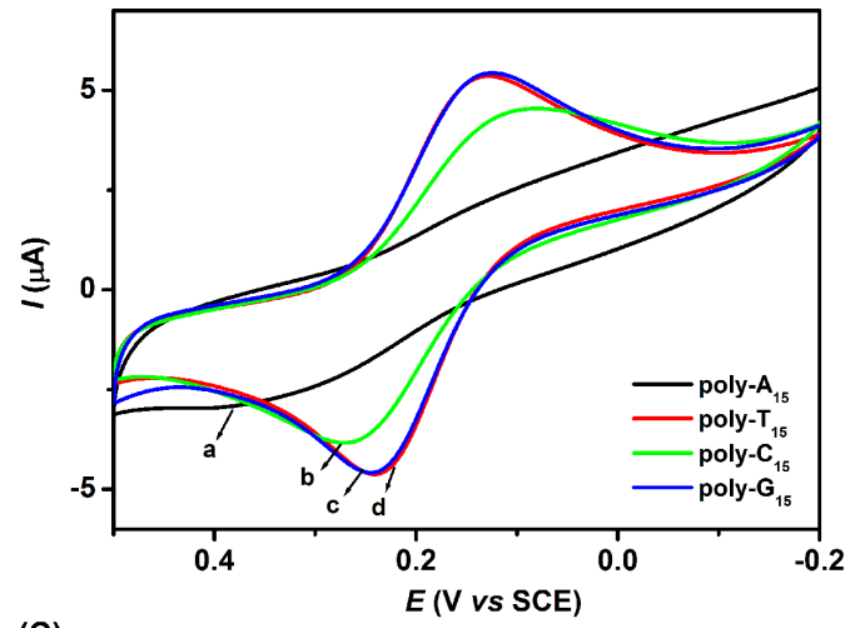

(C)

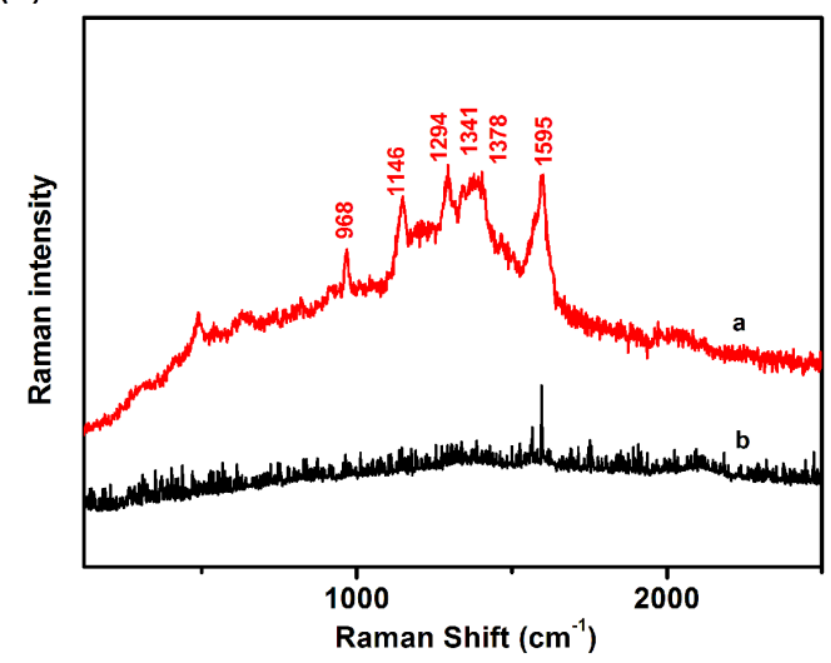

(B)

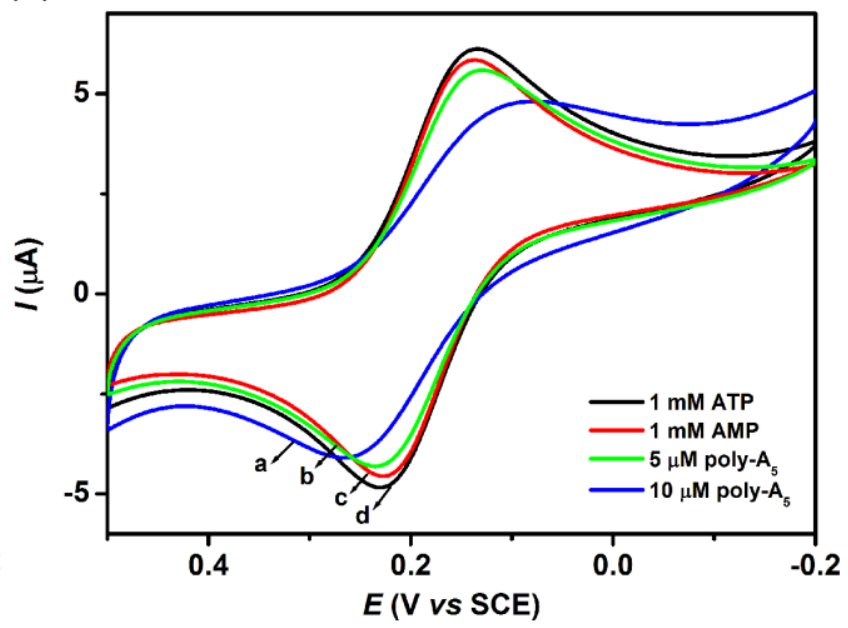

Fig. 4. (A) $\mathrm{CV}$ curves of $\left[\mathrm{Fe}(\mathrm{CN})_{6}\right]^{3-}$ on gold electrodes treated with $5.0 \mu \mathrm{M}$ poly- $\mathrm{A}_{15}$ (a), poly- $\mathrm{C}_{15}$ (b), poly- $\mathrm{G}_{15}$ (c), or poly- $\mathrm{T}_{15}$ (d) in $\mathrm{CB}$ (pH 3.0) for 15 min. (B) CV curves of $\left[\mathrm{Fe}(\mathrm{CN})_{6}\right]^{3-}$ on gold electrodes treated with 10.0 (a) or 5.0 (b) $\mu \mathrm{M}$ poly- $\mathrm{A}_{5}, 1.0 \mathrm{mM}$ AMP (c) or ATP (d) in CB (pH 3.0) for 30 min. (C) Raman spectroscopy recorded on gold electrode surface after 30-min incubation of bare gold electrode with CB (pH 3.0) containing with (a) or without (b) $10.0 \mathrm{mM}$ ATP. 
As clarified in our previous work about the fast adsorption of DNA oligomer on negatively charged citrate-capped $\mathrm{Au}$ nanoparticles [[28,29]], the adenine ( $\mathrm{pK}_{\mathrm{a}}$ 3.5) can be effectively protonated at $\mathrm{pH} 3.0$, which decreases the electrostatic repulsion and favors DNA adsorption onto $\mathrm{Au}$ nanoparticles. To test the possible adsorption of other sequences, we have checked the adsorption behavior of poly- $\mathrm{N}_{15}(\mathrm{~N}=\mathrm{A}, \mathrm{T}, \mathrm{C}, \mathrm{G})$ (Fig. 4A). As expected, $5.0 \mu \mathrm{M}$ poly- $\mathrm{A}_{15}$ adsorbs on electrodes rapidly in 15 min (curve a). A slight change in $\mathrm{CV}$ profile is observed for poly- $\mathrm{C}_{15}$ (curve b). The redox peaks do not change at all for poly- $\mathrm{T}_{15}$ or poly- $\mathrm{G}_{15}$ at $\mathrm{pH} 3.0$ (curve c and d), even after hours of incubation. This agrees well with the fact that neither $\mathrm{T}$ nor $\mathrm{G}$ could be protonated at $\mathrm{pH} 3.0$.

Considering the fast assembly of poly-A DNA, we wonder whether adsorption of shorter poly-A sequences can cause any change in the CV shape. As shown in Fig. 4B, 30-min treatment of $5.0 \mu \mathrm{M}$ poly- $\mathrm{A}_{5}$ results in the same $\mathrm{CV}$ curve as that on the bare electrode (curve b), while 30-min treatment of $10.0 \mu \mathrm{M}$ poly-A5 caused an observable change in $\mathrm{CV}$ profile (curve a). The need for higher $\mathrm{A}_{5}$ concentration might be related to the fact that it is a shorter DNA. At the same time, it also suggests that poly-A DNA is lying flat on the electrode surface so that each nucleotide contributes to the blocking of the $\left[\mathrm{Fe}(\mathrm{CN})_{6}\right]^{3-}$ signal. For AMP and ATP, no change in CV curves was observed even at a much higher concentration up to $1.0 \mathrm{mM}$ (curve $\mathrm{c}$ and $\mathrm{d}$ ). However, the presence of ATP on gold electrode can be verified by Raman spectroscopy (Fig. 4C). Compared with the negligible Raman signals on the control electrode (curve b), the typical peaks at 1595, 1378, and $1146 \mathrm{~cm}^{-1}$ can be assigned to vibration of a ring mode, a ring mode/ribose $\mathrm{CH}$, $\mathrm{OH}$ bending, and nonbridging phosphate of ATP [[28,33]] (curve a). Notably, no citrate ions was detected to gold electrode even at an ultrahigh concentration $(250 \mathrm{mM})$, according to the absence of its typical $\mathrm{C}=\mathrm{O}$ vibration $\left(\sim 1750 \mathrm{~cm}^{-1}\right)$ in Raman spectrum. This confirms that only ATP is attached on the gold surface. Therefore, the small negative-charged molecule such as ATP can also bind to gold surface effectively, but cannot form a dense barrier (as poly- $\mathrm{A}_{15}$ ) to block the access of $\left[\mathrm{Fe}(\mathrm{CN})_{6}\right]^{3-}$ due to its limited molecular volume. 
To test whether this low $\mathrm{pH}$ loaded non-thiolated DNA probe could be used for DNA hybridization, we next employed DNA1 with 9-adenine on its 5 '-end for immobilization and a 12-mer hybridization sequence. The same sequence with also a thiol label (SH-DNA1) was employed for comparison. The bare electrode has a large current as expected and immobilization of both thiolated and non-thiolated DNA produced a low current (Fig. 5A). Hybridization of the target DNA resulted in current increase since the duplex DNA can bind to more $\left[\mathrm{Ru}\left(\mathrm{NH}_{3}\right)_{6}\right]^{3+}$ complexes [30,31]. The amount of signal increase was comparable between the thiolated and non-thiolated probe DNA. The signal increase is due to the specific hybridization event since very little change is observed with a non-target DNA (Fig. 5B).
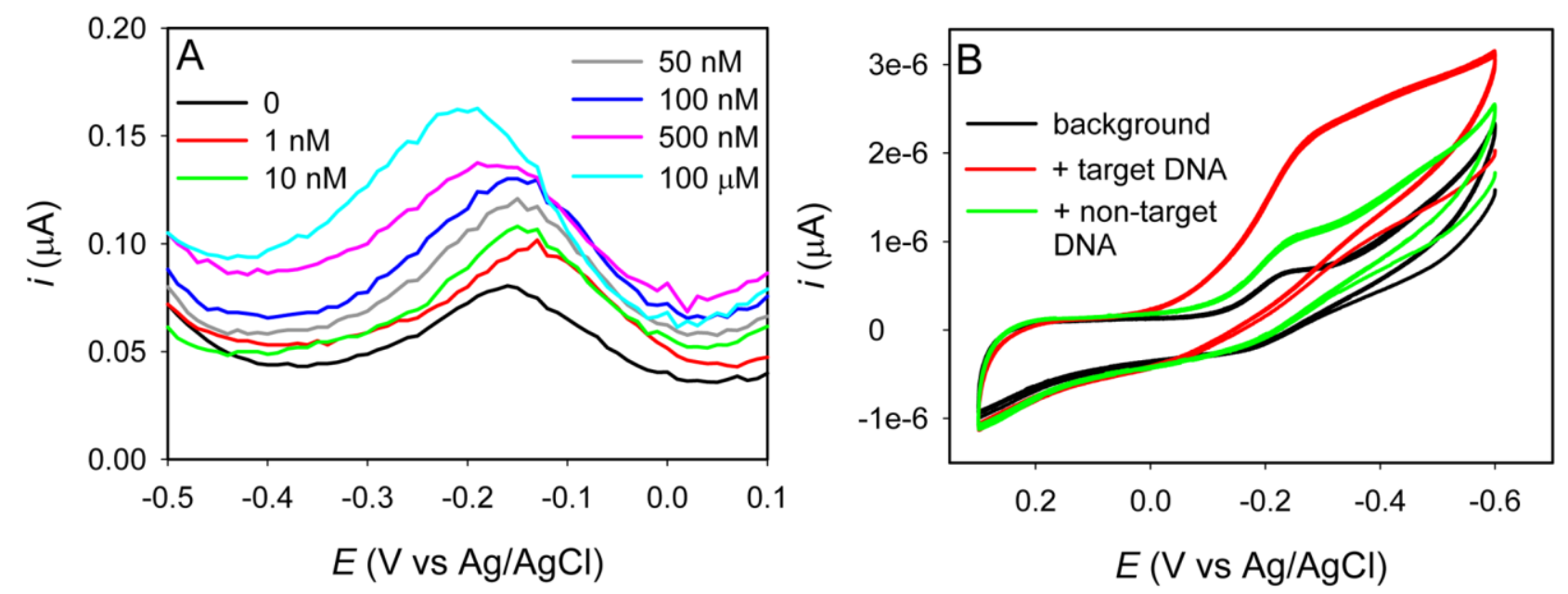

Fig. 5. (A) Square wave voltammetry curves of non-thiolated probe DNA immobilized with the low $\mathrm{pH}$ method to hybridize with various concentration of the target DNA. (B) CV of the probe in the presence of the target DNA and non-target DNA.

\section{Conclusions}

In summary, we reported a method for fast adsorption of non-thiolated DNA oligomers on gold electrode. Compared with the common overnight incubation at neutral $\mathrm{pH}$, the lower $\mathrm{pH}$ can significantly promote the adsorption processes, enabling the efficient adsorption even in 30 min. The rationale behind this is that the protonation of $\mathrm{A}$ and $\mathrm{C}$ at low $\mathrm{pH}$, reducing the negative charges 
on DNA and facilitating their binding to gold surface. This work may offer a meaningful strategy for low-cost and fast fabrication of novel DNA assembled biosensors. While this work was in revision, we noticed a paper by $\mathrm{Li}$ and co-workers using the low $\mathrm{pH}$ method to load thiolated DNA [34].

\section{Acknowledgment}

The research is supported by National Natural Science Foundation of China (20905012), the University of Waterloo, the Canadian Foundation for Innovation, the Ontario Ministry of Research \& Innovation, the Natural Sciences and Engineering Research Council (NSERC) of Canada, and the Emerging Leaders in the Americas Program (ELAP).

\section{Reference}

[1] I. Willner, M. Zayats, Angew. Chem., Int. Ed. 46 (2007) 6408-6418.

[2] C.H. Fan, K.W. Plaxco, A.J. Heeger, Proc. Natl. Acad. Sci. U.S.A. 100 (2003) 9134-9137.

[3] Y. Xiao, B.D. Piorek, K.W. Plaxco, A.J. Heeger, J. Am. Chem. Soc. 127 (2005) 17990.

[4] R. Polsky, R. Gill, L. Kaganovsky, I. Willner, Anal. Chem. 78 (2006) 2268-2271.

[5] D. Chen, H. Feng, J. Li, Chem. Rev. 112 (2012) 6027-6053.

[6] D. Li, S.P. Song, C.H. Fan, Acc. Chem. Res. 43 (2010) 631-641.

[7] H. Wang, R.H. Yang, L. Yang, W.H. Tan, ACS Nano 3 (2009) 2451-2460.

[8] D. Chen, G. Wang, J.H. Li, J. Phys. Chem. C 111 (2007) 2351-2367.

[9] Y. Xiao, A.A. Rowe, K.W. Plaxco, J. Am. Chem. Soc. 129 (2007) 262-263.

[10] B.R. Baker, R.Y. Lai, M.S. Wood, E.H. Doctor, A.J. Heeger, K.W. Plaxco, J. Am. Chem. Soc. 128 (2006) 3138-3139.

[11] I. Willner, B. Willner, E. Katz, Bioelectrochemistry 70 (2007) 2-11. 
[12] X. Mao, J.H. Jiang, X.M. Xu, X. Chu, Y. Luo, G.L. Shen, R.Q. Yu, Biosens. Bioelectron. 23 (2008) 1555-1561.

[13] C.Y. Deng, J.H. Chen, Z. Nie, M.D. Wang, X.C. Chu, X.L. Chen, X.L. Xiao, C.Y. Lei, S.Z. Yao, Anal. Chem. 81 (2009) 739-745.

[14] Y.L. Zhang, Y. Wang, H.B. Wang, J.H. Jiang, G.L. Shen, R.Q. Yu, J.H. Li, Anal. Chem. 81 (2009) 1982-1987.

[15] Y. Jin, X. Yao, Q. Liu, J.H. Li, Biosens. Bioelectron. 22 (2007) 1126-1130.

[16] X. Zuo, S. Song, J. Zhang, D. Pan, L. Wang, C. Fan, J. Am. Chem. Soc. 129 (2007) $1042-1043$

[17] T.M. Herne, M.J. Tarlov, J. Am. Chem. Soc. 119 (1997) 8916-8920.

[18] A.B. Steel, R.L. Levicky, T.M. Herne, M.J. Tarlov, Biophys. J. 79 (2000) 975-981.

[19] A.B. Steel, T.M. Herne, M.J. Tarlov, Anal. Chem. 70 (1998) 4670-4677.

[20] L.K. Wolf, Y. Gao, R.M. Georgiadis, Langmuir 20 (2004) 3357-3361.

[21] A.W. Peterson, R.J. Heaton, R.M. Georgiadis, Nucleic Acids Res. 29 (2001) 5163-5168.

[22] H. Kimura-Suda, D.Y. Petrovykh, M.J. Tarlov, L.J. Whitman, J. Am. Chem. Soc. 125 (2003) 9014-9015.

[23] A. Opdahl, D.Y. Petrovykh, H. Kimura-Suda, M.J. Tarlov, L.J. Whitman, Proc. Natl. Acad. Sci. U.S.A. 104 (2007) 9-14.

[24] S.M. Schreiner, D.F. Shudy, A.L. Hatch, A. Opdahl, L.J. Whitman, D.Y. Petrovykh, Anal. Chem. 82 (2010) 2803-2810.

[25] S.M. Schreiner, A.L. Hatch, D.F. Shudy, D.R. Howard, C. Howell, J. Zhao, P. Koelsch, M. Zharnikov, D.Y. Petrovykh, A. Opdahl, Anal. Chem. 83 (2011) 4288-4295.

[26] H. Pei, F. Li, Y. Wan, M. Wei, H. Liu, Y. Su, N. Chen, Q. Huang, C. Fan, J. Am. Chem. Soc. 
134 (2012) 11876-11879.

[27] X. Zhang, B. Liu, M.R. Servos, J. Liu, Langmuir 29 (2013) 6091-6098.

[28] X. Zhang, B. Liu, N. Dave, M.R. Servos, J. Liu, Langmuir 28 (2012) 17053-17060.

[29] X. Zhang, M.R. Servos, J. Liu, Chem. Comm. 48 (2012) 10114-10116.

[30] M. Steichen, Y. Decrem, E. Godfroid, C. Buess-Herman, Biosens. Bioelectron. 22 (2007) 2237-2243.

[31] M.A. Lapierre, M. O'Keefe, B.J. Taft, S.O. Kelley, Anal. Chem. 75 (2003) 6327-6333.

[32] R. Georgiadis, K.P. Peterlinz, A.W. Peterson, J. Am. Chem. Soc. 122 (2000) 3166-3173.

[33] X. Zhang, M.R. Servos, J. Liu, J. Am. Chem. Soc. 134 (2012) 7266-7269.

[34] Z. F. Gao, J.B. Gao, L.Y. Zhou, Y. Zhang, J.C. Si, H.Q. Luo, N.B. Li, RSC Adv. 3 (2013) 12334-12340.

The authors declare that there is no conflict of interest for this work. This manuscript has not been published previously and is not under consideration for publication elsewhere. 